\title{
Alternative surgical approaches for challenging cases in thoracic surgery-Preface
}

I am pleased to present this fournal of Visualized Surgery special series dedicated to "Alternative surgical approaches for challenging cases in thoracic surgery".

In the last decade, thoracic surgery has rapidly moved forward to new approaches. The introduction and diffusion of VATS lobectomy represents a watershed and now this technique represents the gold standard for pulmonary resection. Progressively, the indication for a minimally invasive approach moved from initial stage pulmonary disease to more advanced ones, with resection extended to other organs, invading fields generally considered reserved to open approaches. Concurrently, new approaches emerged as robotic surgery, no more limited to the mediastinal pathology.

With the increasing experience, also challenging cases are now approached through minimally invasive procedure or hybrid ones.

We therefore aim to provide with this focused series an overview about the possible and, sometimes, unprecedented approaches to complex cases. This may be helpful to other surgeons when facing challenging cases and to stimulate their imagination, which represents one of the fundamental elements for the progress of surgery.

I therefore hope you will enjoy reading these interesting articles.

\section{Acknowledgments}

Funding: None.

\section{Footnote}

Provenance and Peer Review: This article was commissioned by the editorial office, Fournal of Visualized Surgery for the series "Alternative Surgical Approaches for Challenging Cases in Thoracic Surgery". The article did not undergo external peer review.

Conflicts of Interest: The author has completed the ICMJE uniform disclosure form (available at https://jovs.amegroups.com/ article/view/10.21037/jovs-21-18/coif). The series "Alternative Surgical Approaches for Challenging Cases in Thoracic Surgery" was commissioned by the editorial office without any funding or sponsorship. FR served as the unpaid Guest Editor of the series and serves as an unpaid editorial board member of fournal of Visualized Surgery from August 2019 to July 2021. The author has no other conflicts of interest to declare.

Ethical Statement: The author is accountable for all aspects of the work in ensuring that questions related to the accuracy or integrity of any part of the work are appropriately investigated and resolved.

Open Access Statement: This is an Open Access article distributed in accordance with the Creative Commons AttributionNonCommercial-NoDerivs 4.0 International License (CC BY-NC-ND 4.0), which permits the non-commercial replication and distribution of the article with the strict proviso that no changes or edits are made and the original work is properly cited (including links to both the formal publication through the relevant DOI and the license). See: https://creativecommons.org/ licenses/by-nc-nd/4.0/. 


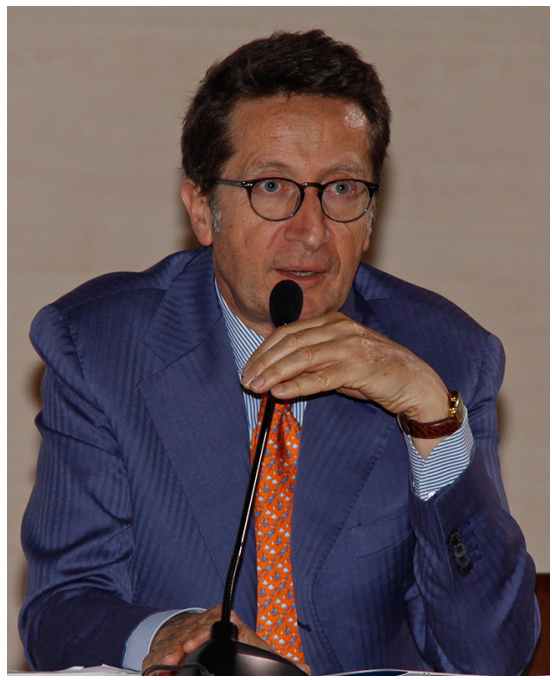

Federico Rea

Federico Rea, MD

Department of Cardio-Thoracic and Vascular Sciences, Division of Thoracic Surgery, University of Padova, Padova, Italy. (Email: federico.rea@unipd.it) Received: 06 April 2021; Accepted: 24 April 2021; Published: 20 July 2021. doi: 10.21037 /jovs-21-18

View this article at: http://dx.doi.org/10.21037/jovs-21-18

doi: $10.21037 /$ jovs-21-18

Cite this article as: Rea F. Alternative surgical approaches for challenging cases in thoracic surgery-Preface. J Vis Surg 2021;7:23. 